\title{
On the Cultivation Model of Core Literacy Integration of English Major in Colleges and Universities Based on Discipline Competition-A Case Study of Jingchu University of Technology
}

\author{
Qian $\mathrm{Luo}^{1, *}$

\begin{abstract}
${ }^{1}$ Jingchu University of Technology, Jingmen, Hubei 448000, China
\end{abstract} \\ *Corresponding author.Email: $15475821 @ q q . c o m$
}

\begin{abstract}
\section{INTRODUCTION}

Discipline competition serves as an important carrier to improve college students' professional core ability, innovative ability, practical ability, and team spirit, as well as an effective way to cultivate innovative talents. However, the author searched resource databases such as Wanfang, CNKI, and Weipu with "discipline competition teaching" as the keyword, and it turns out that China has just set off in related research. To be specific, the relevant academic paper is small in number, and many issues require further research and application. According to existing achievements, deficiencies of related research and practice are mainly as follows:
\end{abstract}

The paper starts from foreign language discipline competition and aims to improve the quality of education and teaching. Based on the analysis of the role of discipline competition in talent cultivation, it is attempted to construct a curriculum teaching system for English major by revising teaching plans, promoting the reform of teaching content and teaching methods, and strengthening the training of discipline competition teachers.

Finally, it is expected to put forward new ideas for cultivating talents with core literacy.

Keywords: competition, cultivation model, discipline competition, core literacy

\subsection{Simple Research Objects and Research Perspectives}

On the one hand, researchers mainly focus on college English courses. For example, Jiang Lixiang (2016) explored the role and significance of organizing and guiding college students to participate in English discipline competition in her paper Promote College English Teaching through College English Discipline Competition. On the other hand, researchers study only from several perspectives such as the role of discipline competition in the second classroom, the improvement of reading and writing skills, professional quality, etc. However, it lacks macro research from a commanding height. For example, $\mathrm{Xu}$ Taili (2013) proposed the development of the second classroom of English major based on discipline competition in his paper Promote the Development of the Second Classroom of English Major based on Discipline
Competition. Therefore, it can be seen that the existing research is mainly concerned with the significance and role of discipline competition in English curriculum, the second classroom, professional quality, etc. However, it performs poor in the integration of discipline competition with English major curriculum, models, and methods. In addition, only a few research pays attention to the integration of domestic discipline competition with English teaching.

\subsection{The Inconsistence of Discipline Competition and Actual Teaching Needs}

According to surveys, it is found that some colleges and universities take discipline competition as an important means to enhance their popularity and test teaching achievements. Consequently, they tend to concentrate limited teaching resources on a small number of outstanding students, thus resulting in a narrower coverage of beneficial owners. In addition, teachers impart knowledge based on previous experience, and they like to adopt cramming method of teaching to quickly improve the competition grades in a short term. Therefore, the imperceptible role of discipline competition in the cultivation of students' core literacy has not been realized.

\subsection{Lack of the Systematic Organization of the Laws and Trends Behind Cases}

In recent years, English competition is characterized by diversification. And competitions with various content and in all forms have been organized by diverse institutions, including education departments of all levels, authoritative 
media, and industry associations. Despite some practical success, colleges and universities perform poor in organizing the laws and trends behind these cases in a systematic manner. In other words, it is in great demand to summarize the corresponding mechanisms of the integration of discipline competition into the main courses of applied talent cultivation.

\section{THE CONNOTATION AND SIGNIFICANCE OF CORE LITERACY OF ENGLISH MAJOR IN COLLEGES AND UNIVERSITIES}

At the end of the 20th century, the Organization for Economic Cooperation and Development (OECD) and the European Union (EU) successively proposed the concept of core literacy in the face of challenges brought by the information era. Subsequently, global countries tried to interpret and construct core literacy models from different perspectives. In this context, the Ministry of Education of People's Republic of China (MOE) carried out a reform in basic education curriculum based on core literacy in 2014 . In particular, General High School Curriculum Standards in 2017 explained the connotation and definition of core literacy of English major from aspects such as language ability, cultural character, thinking quality, learning ability, and interdisciplinary common literacy. In addition, it was stated in the Standards that the teaching purpose of English discipline is going to be shifted from the original cultivation of students' comprehensive language ability to the current cultivation of their core literacy of English discipline. In January 2018, MOE announced the implementation of National Standards for the Quality of Undergraduate Education in General Colleges and Universities, which clarified the requirements for cultivating English talents in terms of quality, knowledge, and ability. No specific concept has been made on the core literacy of English major in relevant documents and research. But by comparing two programmatic documents on English major in high schools and universities, it is not difficult to discover that both of the two emphasize that students should develop correct thinking character, value orientation and the knowledge of discipline, which should be regarded as the basic core literacy of English major. Moreover, colleges and universities focus on highlighting Chinese feelings, international vision, critical thinking ability, and innovative ability in terms of English major, thus forming a core quality group of interdisciplinary knowledge structures. In summary, it can be seen that the core literacy of English major in colleges and universities takes roots in the background of the 21st century, with a goal of cultivating high-quality English talents. In addition, such a model reflects the concept of holistic education and is conducive to promoting the sustainable development of students

\section{THE ROLE OF THE CULTIVATION MODEL OF CORE LITERACY INTEGRATION OF ENGLISH MAJOR IN COLLEGES AND UNIVERSITIES BASED ON DISCIPLINE COMPETITION}

\author{
3.1. Consistent with Relevant Documents \\ Requirements for Higher Education and \\ Teaching Reform at All Levels
}

40 Articles of Higher Education in the New Era proposed to "deepen teaching reform by stimulating students' interest and potential in learning" and to "encourage students to gain credits through social practice, scientific research, innovation and entrepreneurship, competitions, etc." National Standards for the Quality of Undergraduate Education in General Colleges and Universities also suggested that "English major emphasizes practice and application". In May 2019, the Academic Affairs Office of Jingchu University of Technology issued Notice on Regulating the Management of Student Discipline Competition (Draft for Solicitation of Comments), which includes student discipline competition into the management of the educational administration system. The above-mentioned documents have shown that higher education and teaching management departments at all levels put the role and significance of discipline competition high on the agenda, which requires more standardized and strict management.

\subsection{Conducive to Improving the Quality of English Talents}

The cultivation model of core literacy integration of English major in colleges and universities based on discipline competition is conducive to improving students' core literacy in aspects as follows: critical thinking ability, innovative ability, practical ability, and cross-cultural communication ability. In addition, it promotes the construction of teaching style and academic style, and then realizes the integration of "language teaching" with "quality education". On this basis, it is possible to explore a teaching model and talent cultivation model that integrates academic competition with the content, cases, and methods of English major. In this way, students are able to enhance their English practical ability, innovative ability and humanistic quality, and their self-confidence and sense of accomplishment can be achieved. In the end, colleges and universities can cultivate compound applied talents with high comprehensive quality, high professional level, excellent cross-cultural communication skills, and strong practical and innovative ability. 


\section{PRACTICE OF THE CULTIVATION MODEL OF CORE LITERARY INTEGRATION OF ENGLISH MAJOR IN COLLEGES AND UNIVERSITIES BASED ON DISCIPLINE COMPETITION}

To further deepen the reform of undergraduate English teaching, the School of Foreign Languages of Jingchu University of Technology starts from the reality and aims to cultivate applied foreign language talents. In this context, the college has carried out the practice of "the cultivation model of core literary integration of English major in colleges and universities based on discipline competition" from May 2018. In the past three years, more students of English major have engaged in discipline competitions of all levels, and their winning rate has also been on the increase. To be specific, a total of 26 people won provincial and national English disciplines competition awards in the "FLTRP" Cup Competition of English writing, reading, and speech, CCTV "Star of Outlook", "21st Century" Cup National English Speech Competition, and National English Vocabulary Competition. Meanwhile, the college also constructed a curriculum system based on the core literacy integration of English major, which helps solve the problems of narrow coverage of English discipline competition, inadequate professional comprehensive abilities of students of English major, and the overvalue on skills over abilities. The main measures of the project are as follows:

\subsection{Combine Discipline Competitions with Core Courses of English Major}

According to National Standards for the Teaching Quality of Foreign Languages and Literatures issued in 2018, the core courses of English major are divided into two categories: English skills courses and professional knowledge courses. The cultivation model of core literacy integration of English major in colleges and universities is characterized by the integration of the content and form of discipline competitions with the classroom teaching of the core courses of English major, which leads to a discipline competition curriculum system with professional characteristics. In terms of top-level design, the college teaching and research office takes roots in the revision of undergraduate cultivation plan of English major. On this basis, it systematically plans the curriculum system for the core literacy of English major based on their own school-running practice and the orientation of applied talent cultivation. In terms of teaching content, it should organize the content and question types related to the competitions, as well as introduce knowledgeable and critical competition content into the usual classroom teaching, so as to improve students' comprehensive English ability. For example, the college may introduce the topics of previous English reading and writing competitions into related courses, and then ameliorate content closely related to discipline competitions. In terms of teaching methods, the form of competition can be applied to classroom teaching activities. In this way, it is able to combine the two in an organic manner, and then further reflect the role of discipline competition in the cultivation of students' comprehensive application ability. For example, the college may introduce English speech contests, English drama performance and incentive mechanisms into comprehensive English classroom, so as to stimulate students' learning enthusiasm and improve the quality of English classroom teaching.

\subsection{Combine Discipline Competitions with Practical Teaching of English Major}

The practical teaching of English major is aimed at cultivating students' core literacy such as critical thinking ability and international vision, which provides valuable opportunities for students to improve language practical ability. According to National Standards, the plan of practical teaching of English major should be based on talent cultivation plan. In addition, the training content and procedures should be carefully designed based on discipline competitions, and then discipline competitions, learning interest groups, and academic clubs should be carried out, thus combining discipline competitions with practical teaching of English major. However, the current practical teaching of English major is limited by forms, which leads to the disconnection of students' language application ability and social needs, and inadequate professional comprehensive abilities of students of English major. To this end, Jingchu University of Technology divides discipline competition into four stages: school, college, province, and country. In addition, the school tries to select talents for various discipline competitions by encouraging students to participate in school-level competitions. Secondly, the school constructs a dynamic English competition talent database according to grade, interest, and specialty. In addition, lectures or activities are carried out for students regularly or irregularly. Meanwhile, discipline competitions and activities are included into the professional practical teaching system and the credit system management, which hence innovates the practical teaching model of liberal arts majors.

\subsection{Combine Discipline Competitions with English Teacher Cultivation}

The guidance of discipline competition instructors provides strong support and guarantee for better competition grades. However, the cultivation of mature and excellent instructors is not accomplished at one stroke, but requires a long period of teaching accumulation and summary. Every teacher has their own discipline expertise and direction. Therefore, it is necessary to give play to the strength and wisdom of the group and strengthen mutual communication. Considering the continuity of teaching, it 
is necessary to establish a teacher guidance team that includes the elder teacher, the adulthood teacher and the young teacher, as well as improve the training of discipline competition teachers. The above-mentioned measures are conducive to improving the teaching and research capabilities of English teachers in colleges and universities and constructing an excellent teacher team.

\section{CONCLUSION}

In summary, in the course of integrating discipline competitions into the core competence cultivation of English major, it is possible to propose new ideas for constructing an English major curriculum teaching and practice system with college characteristics and cultivating high-quality talents with core competencies in English major through ways as follows: rationally define the core competence modules of English major, analyze the significance and role of discipline competitions in talent cultivation, revise teaching plans, reform teaching content and teaching methods, and strengthen training for discipline competition teachers.

\section{ACKNOWLEDGMENT}

This research was financially supported by the teaching research project of Jingchu University of Technology "On the Cultivation Model of Core Literacy Integration of English Major in Colleges and Universities Based on Discipline Competition" (JX2019-066), Research on Super language from the perspective of memetics
(YB201907/651933), A study on the washback effect of high-risk test on English teaching - A Case Study of TEM4 and TEM8. (S202011336057), and research on the cultivation of EFL learners' cultural confidence in the college English education (19ZD072).

\section{REFERENCES}

[1] Du Xuexin, Research and Practice of Blended Learning Mode for English Major, Southeast University Press, 2018.10, p.53

[2] He Jihong, Huang Lihe, Integrated and Diversified English Education, Tongji University Press, 2017.04, p.3

[3] He Jihong, Huang Lihe. Integrated and Diversified English Education [M]. Shanghai: Tongji University Press, 2017.04.

[4] Jiang Li, On the Integration Path of English Classroom Teaching and Student Competition [J]. Journal of Jilin Radio and Television University, 2019, (09):12-13.

[5] Peng Jian, Promote the Practical Research on Quality Education and Teaching of College English Major through Discipline Competition and Activity-A Case Study of Changsha Normal University [J]. Journal of Hunan University of Science and Technology, 2017, 38(02):126-128+134. 